\title{
Effect of Cinnamon Bark on Glucose and Lipids Levels of Male Egyptian Type Ii Diabetes Mellitus Patients
}

\author{
Ghada Z A Soliman \\ Biochemistry Department, National Nutrition Institute, Cairo
}

\begin{abstract}
The present study aimed to determine the effect of cinnamon bark on blood glucose, triacylglycerol, total cholesterol, HDL cholesterol, and LDL cholesterol levels in patients with type 2 diabetes. A total of 30 patients (male) with type 2 diabetes, aged 30-50 years, were divided into two groups. Groups 1 and 2 consumed 1.5 or $3 \mathrm{~g}$ of cinnamon daily, respectively for 45 days. Results: After 45 days, cinnamon reduced the mean fasting serum glucose (17.63; 24.65\%), total cholesterol (17.61, 24.25\%), LDL cholesterol (21.73, 31.86\%), triacylglycerol (19.62, 22.1\%), and phospholipids $(15.35,26.02 \%)$ levels. Changes in HDL cholesterol were not significant. It, also, reduced body weight, thus decreasing its body mass index (BMI). Conclusions: The results of the present study demonstrated that intake of $1.5 \& 3.0 \mathrm{~g}$ of cinnamon per day reduces serum glucose, triacylglycerol, LDL cholesterol, and total cholesterol in patients with type 2 diabetes and suggest that the inclusion of cinnamon in the diet of patients with type 2 diabetes may reduce risk factors associated with diabetes and cardiovascular diseases, it, also, improves their body mass index (BMI).
\end{abstract}

Key words: NIDDM, Lipid profile, Cinnamon

\section{INTRODUCTION}

Diabetes is a predominant public health concern affecting a lot of people allover the world. The disease causes substantial morbidity, mortality, and long-term complications and remains an important risk factor for cardiovascular disease (1). With increasing rates of childhood and adult obesity, diabetes is likely to become even more prevalent over the coming decade. There is an increasing trend allover the world to use complementary and alternative medicine (CAM) among the general public ${ }^{(2)}$. Studies have examined so many ways as mind-body techniques, biofeedback and others ${ }^{(3,4)}$, but most of the literature, however, has focused on herbs or other dietary supplements. Herbal remedies or other dietary supplements taken by mouth are to be consistently among the top CAM therapies used ${ }^{(5-7) .}$ Plant derivatives with purported hypoglycemic properties have been used in folk medicine and traditional healing systems around the world. Many plants as spices, bitter melon, onions, garlic, fenugreek or its extract have anti diabetic (hypoglycemic) and/or hypocholesterolemic effect with different degrees. Spices such as cinnamon and turmeric display insulin-enhancing activity in vitro ${ }^{(8-10)}$ through improving glucose 
metabolism, lipid metabolism, antioxidant status, and capillary function $^{(\mathbf{1 1 )}}$. In general, the scientific literature on the efficacy of CAM especially spices in the treatment of diabetes is relatively sparse and heterogeneous. Based on WHO recommendation on diabetes mellitus $^{(\mathbf{1 2})}$, investigations of hypoglycemic agents of plant origin used in traditional medicine are important. Cinnamon bark (Cinnammoum zeylanicum; Cinnammoum cassia) is one of the world's oldest spices. In folk (remedy) medicine it is used for its carminative, stimulant and antiseptic properties. Khan et al., $199{ }^{\left({ }^{(8)}\right.}$ suggested that cinnamon has insulin potentiating activity.

\section{AIM OF THE WORK}

The purpose of current study was to determine the effect of cinnamon bark powder on blood glucose, triacylglycerol, total cholesterol, HDL cholesterol, and LDL cholesterol levels in people with type 2 diabetes.

\section{SUBJECTS \& METHODS}

\section{Analysis of Cinnamon}

Cinnamon (Cinnamomum cassia) bark powder was purchased from local markets in Cairo. It was analyzed to determine chemical (13) and mineral composition. Minerals were measured in the ash using atomic absorption, Unicam $929^{(\mathbf{1 4})}$.

\section{Subjects (Selection Criteria)}

The study was conducted on 30 patients of non insulin dependent diabetes mellitus (NIDDM, type II) patients, who were attending governmental and Non-Governmental Organization (NGO's) as hospitals and clinics during the years 20012004 . Their age range was $30-50$; with a mean of $41.72 \pm 1.59$ years. Their BMI range was 26.26-31.42, with a mean of $29.21 \pm 0.46 \mathrm{~kg} / \mathrm{m}^{2}$. The duration of diabetes was $8.0 \pm 0.7$; with a mean of 4.5-17 years. Their fasting blood (serum) glucose levels range between 254.65 and $327.05 \mathrm{mg} / \mathrm{dl}$. The selected subjects were nonsmokers, not taking any medicines other than oral anti-diabetic pills for the past four years (at least). The diagnosis of type II diabetes mellitus was based on the criteria of ${ }^{(\mathbf{1 5})}$.

Anthropometrics Measurements

Weight (wt) and height (ht) were measured in indoor clothing without shoes and body mass index (BMI) was calculated where $\mathrm{BMI}=\mathrm{wt}(\mathrm{kg}) / \mathrm{ht}$ $\left(\mathrm{m}^{2}\right)$.

\section{Research Design}

Cinnamon was put into capsules. Each capsule contained $500 \mathrm{mg}$ of cinnamon. The patients were given [1.5 g ( 1 x 3 capsules/day) or $3 \mathrm{~g}$ ( $2 \times 3$ capsules/day) for 45 days]. The patients take their capsule supply $( \pm 10 \%$ extra $)$ every two weeks and they were asked to bring the remaining. Compliance was monitored by capsule count and personnel contact with the subjects and, also, through their physician. The study was conducted for 45 days with 30 individuals with male, type 2 , obese and/or overweight diabetics divided into two groups. Group 1 consumed three $500 \mathrm{mg}$ (1x3) capsules of cinnamon/day; group 2 consumed six capsules $(2 \times 3)$ of cinnamon/day. Subjects consumed their normal diets and continued their 
medications throughout the study. The patients were instructed to take the capsules immediately after meals (breakfast, lunch, dinner, sometimes they skip dinner and take double after lunch).

\section{Blood Sampling}

Fasting blood samples were drawn after overnight fasting and collected. Blood was centrifuged to separate serum. They were kept at $80^{\circ} \mathrm{C}$ if not analyzed immediately. Glucose, cholesterol (ch or C), high density lipoprotein cholesterol (HDLC), low density lipoprotein cholesterol (LDL-C), very low density lipoprotein cholesterol (VLDL-C), Ch/HDL-C, HDL-C/LDL-C, triacylglycerol (TG) was determined. Repeated freezing and thawing was avoided.

\section{The Analytical Methods of Blood} Serum:

Total cholesterol, TC, (Bio Mérieux kits $\left.{ }^{(16,17)}\right)$, total triacylglycerol, TG, (Bicon kits ${ }^{(\mathbf{1 8})}$ ), total phospholipids ${ }^{(19)}$, serum HDL (Bio Mérieux kits ${ }^{(20,21)}$ ), serum LDL (Bio Mérieux kits ${ }^{(22-24)}$ ) contents were determined using suitable kits reagents. VLDL-C was determined by using the following equation: VLDL$\mathrm{C}=$ total cholesterol - (HDL-C + LDLC).

\section{Statistical Analysis}

Data are expressed as Mean \pm SE. Data were assessed by paired t-test (25,26).

\section{RESULTS}

Data of table (1) shows anthropometeric measurements of both group 1 and 2 (G $1 \& 2$ ). The data revealed that there was no significant difference between the two groups concerning age, weight and BMI. Taking 1.5 or $3 \mathrm{~g}$ of cinnamon led to significant decreases in weight and improves BMI after 45 days (6 weeks). Mean decrease was 7.34, $6.51 \%$ for $\mathrm{G} 1$ \& 2 respectively. In group 1, 33.33\% were obese (BMI $\geq 30.0)$ and $66.67 \%$ were overweight (BMI $\geq 25.0$ ); the obese ones turned into overweight after taking cinnamon, while overweight ones $50 \%$ of them turned into normal and the remaining $50 \%$ remained overweight with lower BMI. In group $2,46.67 \%$ were obese and $53.33 \%$ are overweight; the obese ones turned into overweight after taking cinnamon, while overweight ones $42.86 \%$ of them turned into normal and the remaining $\quad 57.14 \% \quad$ remained overweight with lower BMI (table 2). The duration of diabetes in diabetic type 2 patients, NIDDM, was: G 1: $8.2 \pm 0.72 ; \mathrm{G} 2: 8.73 \pm 0.76 \mathrm{y}$.

Data of table (3) reveal the chemical and mineral composition of cinnamon. Analysis shows that cinnamon contains (g/100 g): 4.2 Protein, 5.5 fats, 3.14 ash (mineral), 10.5 crude fibers, and 76.16 carbohydrates with total calorie of $376.94 \mathrm{Kj} / 100 \mathrm{~g}$. The mineral contents of cinnamon $(\mathrm{mg} / 100 \mathrm{~g})$ were 55.14 , 527, 82, 40, 0.51, 2.12, 6.05 and 0.29 for $\mathrm{Na}, \mathrm{K}, \mathrm{Mg}, \mathrm{Fe}, \mathrm{Cu}, \mathrm{Zn}, \mathrm{Mn}$ and $\mathrm{Cr}$ respectively.

Data of table (4) shows the mean level of serum glucose and lipoproteins profiles of NIDDM (type 2). Data of table (4) shows that taking $1.5 \mathrm{~g}$ (group 1) or $3 \mathrm{~g}$ (group 2) of cinnamon led to significant decreases in serum glucose levels after 45 days (6 weeks) for both groups. Decreases 
ranged from: 13 to $25 \%$ (mean 17.63 ; G 1), 17.41 to $28.94 \%$ (mean 24.65; $G$ 2). There were, also, significant decreases in serum cholesterol levels in all groups consuming cinnamon. These decreases in serum cholesterol level ranged from: 15.02 to $23.07 \%$ (mean 17.61; G 1), 20.81 to $28.94 \%$ (mean 24.25; G 2). There were nonsignificant changes in HDL-C in the subjects consuming 1.5 or $3 \mathrm{~g}$ of cinnamon for 45 days (6 weeks), only slight increase $(3.15 \% \& 3.35 \%$ for $G$ $1 \& 2$ respectively). Decreases in LDL-C and VLDL-C were significant in both groups. The decrease in LDL$\mathrm{C}$ reaches $21.73 \%$ \& $31.86 \%$ for $\mathrm{G} 1$ \& 2 respectively, while the decrease in VLDL-C in both groups was almost the same $(\approx 17.58 \%)$. Decreases in triacylglycerol levels after 6 weeks of cinnamon consumption ranged from $11.63 \%$ to $25.83 \%$ \& $18.71 \%$ to $25.71 \%$ in $\mathrm{G} 1$ \& 2 respectively. Decreases in phospholipids levels after 45 days (6 weeks) of cinnamon consumption ranged from $6.25 \%$ to $28.06 \%$ \& $17.08 \%$ to $31.64 \%$ in $\mathrm{G} 1$ \& 2 respectively.

Data of table (4) reveals that atherogenic indices of diabetic patients as cholesterol/HDL-C showed a significant decrease after taking the cinnamon capsule while HDLC/LDL-C showed a significant increase after taking the cinnamon capsule for both groups $1 \& 2$. 
Table (1): Anthropometrics measurements of the diabetic patients

\begin{tabular}{|l|c|c|c|c|c|c|c|c|c|c|}
\hline \multicolumn{2}{|c|}{} & & & & G 1 & & & & G 2 & \\
\cline { 4 - 11 } \multicolumn{2}{c|}{} & Age & Duration & Weight & BMI & Age & Duration & Weight & BMI \\
\cline { 3 - 11 } & Year & Year & Kg & $\mathrm{Kg} / \mathrm{m}^{2}$ & Year & Year & $\mathrm{Kg}$ & $\mathrm{Kg} / \mathrm{m}^{2}$ \\
\hline Initial & Mean & & 40.40 & 8.2 & 76.69 & 28.49 & 41.72 & 8.73 & 74.20 & 29.21 \\
\hline & \pm SE & 1.51 & 0.72 & 2.01 & 0.41 & 1.59 & 0.76 & 1.66 & 0.46 \\
\hline Final & Mean & & & & 71.01 & 26.39 & & & 69.37 & 27.32 \\
\hline & \pm SE & & & 1.73 & 0.34 & & & 1.54 & 0.45 \\
\hline & P & I vs F & & & 0.041 & 0.0005 & & & 0.042 & 0.006 \\
\hline \% change & & & & & -7.34 & -7.34 & & & -6.51 & -6.51 \\
\hline
\end{tabular}

Table (2): Distribution of BMI of diabetic patients

\begin{tabular}{|c|c|c|c|c|c|c|c|c|c|}
\hline & \multirow{3}{*}{ BMI } & & \multirow[t]{2}{*}{ G 1} & \multirow[b]{2}{*}{ Final } & & \multirow[b]{2}{*}{ Initial } & \multirow[t]{2}{*}{ G 2} & \multirow[b]{2}{*}{ Final } & \\
\hline & & Initial & & & & & & & \\
\hline & & No & $\%$ & No & $\%$ & No & $\%$ & No & $\%$ \\
\hline Normal & $<25$ & & & & & & & 4 & 26.67 \\
\hline Overweight & $\geq 25-<30$ & 10 & 66.67 & 15 & 100 & 7 & 46.67 & 11 & 73.33 \\
\hline Obese & $\geq 30$ & 5 & 33.33 & & & 8 & 53.33 & & \\
\hline Total & & 15 & & 15 & & 15 & & 15 & \\
\hline
\end{tabular}


Table (3): Analysis of Cinnamon/100 g.

\begin{tabular}{|c|c|c|c|c|c|c|c|c|c|c|c|c|c|c|c|c|}
\hline \multicolumn{2}{|c|}{} & & & Chemical & & & & & & & & & & & & \\
\hline & $\begin{array}{c}\text { Carbo- } \\
\text { hydrate }\end{array}$ & Protein & Moisture & Fat & Fiber & Ash & Calorie & $\mathrm{Na}$ & $\mathrm{K}$ & $\mathrm{Mg}$ & $\mathrm{Fe}$ & $\mathrm{Cu}$ & $\mathrm{Zn}$ & $\mathrm{Mn}$ & $\mathrm{Cr}$ \\
\hline & & $\mathrm{g}$ & & & & & & $\mathrm{mg}$ & $\mathrm{mg}$ & $\mathrm{mg}$ & $\mathrm{mg}$ & $\mathrm{mg}$ & $\mathrm{mg}$ & $\mathrm{mg}$ & $\mu \mathrm{g}$ \\
\hline RDA & & 67.16 & 4.2 & 9.5 & 5.5 & 10.5 & 3.14 & 376.94 & 55.14 & 527 & 82 & 40 & 0.51 & 2.12 & 6.05 & 290 \\
\hline \%RDA & $1.5 \mathrm{~g}$ & & & & & & & & & & 420 & 8 & 900 & 11 & 2.3 & 35 \\
\hline & $3.0 \mathrm{~g}$ & & & & & & & & & & 0.3 & 7.5 & 0.001 & 0.33 & 3.95 & 12.43 \\
\hline
\end{tabular}


Table (4): Clinical characteristics of male NIDDM (type 2)

\begin{tabular}{|c|c|c||c|c|c|c|c|c|c|c|}
\hline & & $\begin{array}{c}\text { Blood } \\
\text { Sugar }\end{array}$ & Cholesterol & HDL-C & LDL-C & VLDL-C & $\begin{array}{c}\text { Triacyl- } \\
\text { glycerol }\end{array}$ & $\begin{array}{c}\text { Phospho- } \\
\text { lipids }\end{array}$ & $\begin{array}{c}\text { Chol } \\
\text { HDL-C }\end{array}$ & $\begin{array}{c}\text { HDL } \\
\text { LDL-C }\end{array}$ \\
\hline G 1 & & & & & & & & & & \\
\hline Initial & Mean & 289.06 & 257.69 & 41.66 & 170.75 & 45.28 & 193.75 & 512.69 & 6.26 & 0.24 \\
\hline & \pm SE & 8.27 & 6.86 & 1.76 & 2.18 & 3.73 & 3.15 & 9.84 & 0.17 & 0.01 \\
\hline Final & Mean & 237.17 & 212.34 & 42.85 & 127.56 & 41.91 & 155.53 & 433.26 & 5.00 & 0.32 \\
\hline & \pm SE & 5.22 & 5.96 & 1.65 & 1.31 & 4.52 & 2.54 & 8.80 & 0.10 & 0.01 \\
\hline & P & 0.00001 & 0.00003 & NS & 0.000001 & 0.044 & 0.000003 & 0.000002 & 0.0003 & 0.000004 \\
\hline & \% Change & -17.63 & -17.61 & 3.15 & -21.73 & -17.58 & -19.62 & -15.35 & -20.18 & 31.71 \\
\hline G 2 & & & & & & & & & & \\
\hline Initial & Mean & 279.62 & 262.16 & 42.65 & 180.13 & 39.37 & 185.20 & 530.94 & 6.22 & 0.24 \\
\hline & \pm SE & 5.22 & 7.26 & 1.83 & 3.22 & 2.81 & 2.43 & 6.39 & 0.12 & 0.01 \\
\hline Final & Mean & 210.60 & 198.25 & 44.04 & 122.54 & 31.67 & 144.18 & 392.71 & 4.56 & 0.36 \\
\hline & \pm SE & 4.23 & 4.95 & 1.85 & 1.68 & 1.88 & 1.57 & 6.57 & 0.10 & 0.01 \\
\hline & P $<$ & 0.000005 & 0.00006 & NS & 0.000002 & 0.03 & 0.000003 & 0.00005 & 0.0000026 & 0.000001 \\
\hline & \% Change & -24.65 & -24.25 & 3.35 & -31.86 & -17.81 & -22.10 & -26.02 & -26.66 & 51.96 \\
\hline
\end{tabular}

$N S=$ Non significant

$P<0.05$ is significant 


\section{DISCUSSION}

Treatment of diabetic patient with cinnamon capsule for 45 days leads to significant reduction of their body weight, which improve their BMI.

Uncontrolled, untreated diabetes mellitus is characterized by elevated blood glucose level. In this study blood glucose level was reduced significantly after taking cinnamon. Cinnamon may reduce blood glucose level through many mechanisms as increasing insulin sensitivity ${ }^{(27)}$ or incorporation of its content of $\mathrm{Mg}$ and $\mathrm{Cr}^{(28,29)}$.

Type II diabetics suffer from insulin resistance, which include decreased stimulation of muscle glycogen synthesis probably due to defects in glycogen synthase activity and glucose uptake ${ }^{(27)}$. They, also, suffer from altered enzymatic activities, such as an increased phosphatase activity and/or seryl phosphorylation of the insulin receptor substrate by glycogen synthase kinase- $3^{(\mathbf{3 0}, 31)}$. Dephosphorylation of the receptor $\beta$ subunit is associated with the deactivation of its kinase activity and, therefore, is associated with insulin signal downregulation ${ }^{(32)}$. Maximal phosphorylation of the insulin receptor is associated with increased insulin sensitivity, which is associated with improved glucose and lipid levels. Extracts of cinnamon was shown to activate glycogen synthase, increase glucose uptake, and inhibited glycogen synthase kinase- $3 \beta^{(\mathbf{3 3}, 34)}$. Extracts of cinnamon, also, was shown to activate insulin receptor kinase and inhibite dephosphorylation of the insulin receptor, leading to maximal phosphorylation of the insulin receptor ${ }^{(33,34)}$. All of these effects would lead to increased insulin sensitivity. It, also, may aid in triggering the insulin cascade system. Since insulin plays a key role in lipid metabolism, and cinnamon can affect insulin then cinnamon may improve glucose and lipids in vivo ${ }^{(33,34)}$. Dhuley $1999^{(35)}$ showed that cinnamon displays antioxidant activity in rats fed a high-fat diet. Cinnamon enhance activity of antioxidant enzymes through counteracted increase in lipid conjugated dienes and hydroperoxides, the primary products of lipid peroxidation.

Magnesium (Mg) has many important functions in the body. There are controversies in the studies. Some studies have suggested that low $\mathrm{Mg}$ level may worsen glucose control in type II diabetes through interrupting insulin secretion from the pancreas and increasing insulin resistance. $\mathrm{Mg}$ deficiency is common in diabetics ${ }^{\mathbf{( 2 8 )}}$. Magnesium is a cofactor in various enzyme pathways involved in glucose oxidation, and it modulates glucose transport across cell membranes. It may increase insulin secretion and/or improve insulin sensitivity and peripheral glucose uptake. In another study (Ghada) ${ }^{1}$ found that magnesium concentration of Egyptian, diabetic, type II patient were significantly lower than normal non-diabetic patient i.e. they have lower concentration of $\mathrm{Mg}$. Cinnamon contain $60 \mathrm{mg} \mathrm{Mg} / 100 \mathrm{~g}$. (table 3), thus 1.5 and $3.0 \mathrm{~g}$. provide 0.26 and 0.51 of the recommended dietary

\footnotetext{
${ }^{1}$ Under publication
} 
allowance $\left(\mathrm{RDA}^{(36)}\right)$ of $\mathrm{Mg}$ respectively.

Chromium (Cr) is an essential trace mineral. Low intake of $\mathrm{Cr}(<20$ $\mu \mathrm{g}$ /day) may decrease the cellular response to insulin and slow the utilization of stored fat (29). $\mathrm{Cr}$ potentiate insulin action ${ }^{(29,37)}$. Insulin increases $\mathrm{Cr}$ transport with transferrin by promoting the movement of transferrin receptors from vesicles to surface membranes and this facilitate $\mathrm{Cr}$ transport to insulin-sensitive cells where it combines with stored apochromodulin and enhances insulin action on glucose metabolism ${ }^{(37)}$. Chromium works closely with diabetes, facilitate glucose uptake into cells, decreases fasting glucose, improves glucose tolerance, lowers insulin and decreases total cholesterol and triacylglycerol while increasing HDL-C. Chromium lowers body weight. All these effects are due to increased insulin sensitivity ${ }^{(\mathbf{2 8})}$. Cinnamon contains $0.29 \mathrm{mg} \mathrm{Cr} / 100 \mathrm{~g}$. (table 3 ), thus 1.5 and $3.0 \mathrm{~g}$ provide 12.43 and $24.86 \%$ of the recommended dietary allowance $\left(\mathrm{RDA}^{(36)}\right)$ of $\mathrm{Cr}$ respectively. RDA of $\mathrm{Cr}$ for human is $35 \mu \mathrm{g} /$ day $^{(37)}$.

\section{CONCLUSIONS}

The current study demonstrates beneficial effects of different levels $(1.5 \& 3 \mathrm{~g} /$ day) of cinnamon on serum glucose, triacylglycerol, LDL cholesterol, and total cholesterol levels in patients with type 2 diabetes. Cinnamon reduced serum glucose, triglyceride, total cholesterol, and LDL cholesterol levels in patients with type 2 diabetes. Because cinnamon would not contribute to caloric intake, diabetics may benefit from the regular inclusion of cinnamon in their daily diet.

\section{REFERENCES}

1. National Diabetes Fact Sheet (1998): National Estimates and General Information on Diabetes. Atlanta, Georgia, Center for Disease Control and Prevention.

2. Payne C. (2001): Complementary and integrative medicine: emerging therapies for diabetes. Part I. Diabetes Spectrum 14:129-131.

3. Bailey B. K., McGrady A. V. and Good M. (1990): Management of a patient with insulin-dependent diabetes mellitus learning biofeedbackassisted relaxation. Diab. Educ., 16: 201-204.

4. Rice B. I. (2001): Mind-body interventions. Diabetes Spectrum 14:213-217.

5. Egede L. E., Ye X., Zheng D., and Silverstein M. D. (2002): The prevalence and pattern of complementary and alternative medicine use in individuals with diabetes. Diabetes Care 25:324329.

6. Yeh G. Y., Eisenberg D. M., Davis R. B., and Phillips R. S. (2002): Complementary and alternative medicine use among patients with diabetes mellitus: results of a national survey. Am. J. Pub. Health 92:1648-1652.

7. Ryan E. A., Pick M. E., and Marceau C. (2001): Use of alternative medicine in diabetes mellitus Diabet. Med., 18: 242245. 
8. Khan A., Bryden N. A., Polansky M. M., and Anderson R. A. (1990): Insulin potentiating factor and chromium content of selected foods and spices. Bio. Trace Element Res., 24:183-188.

9. Broadhurst C. L., Polansky M. M., and Anderson R. A. (2000): Insulin-like biological activity of culinary and medicinal plant aqueous extracts in vitro. J. Agric. Food Chem., 48:849-852.

10. Bailey C. J., and Day C. (1989): Traditional plant medicine as treatments for diabetes. Diabetes Care 12:553-564.

11. Shapiro K., and Gong W. C. (2002): Natural products used for diabetes. J. Am. Pharm. Assoc., 42: 217-226.

12. WHO (1980): The WHO expert committee on diabetes mellitus, technical report series world health organization, Geneva.

13. AOAC (1991): "Official method of analysis of the Association of Official Analytical Chemists. Published by the association of official analytical chemists, Inc., Arlington, USA.

14. AOAC (1984): "Official method of analysis of the Association of Official Analytical Chemists. Published by the association of official analytical chemists, Inc., Arlington, USA.

15. The Expert Committee on the diagnosis of diabetes mellitus 2000. Report of the Expert Committee on the diagnosis of diabetes mellitus (2000). Diabetes Care 23: S4-S19.

16. Richmond W. (1973): Preparation and properties of cholesterol oxidase from
Nocardia Sp. And its application to the enzymatic assay of total cholesterol in serum. Clin. Chem., 19: 1350-1356.

17. Allain C. C., Poor L. S., Chan C. S. G., Richmond W., and Fu P. C. (1974): Enzymatic determination of total serum cholesterol. Clin. Chem., 20: 470475.

18. Buccolo G., and David $H$. (1973): Quantitative determination of triglycerides by the use of enzymes. Clin chem., 19: 476-482.

19. Connerty H. V., Briggs A. R., and Eaton E. H. JR. (1961): Simplified Determination of lipid component of blood serum. Clin. Chem., 7: 43-45.

20. Burstein M., Scholnick H. R. and Monfin R. (1970): Rapid method for the isolation of lipoproteins from human serum by precipitation with polyanions. J. Lipid Res., 11: 585-595.

21. Lopes-Virella M. F., Stone P. G., Ellis S., and Coldwell J. A. (1977): Cholesterol determination in high density lipoprotein separated by three different methods. Clin. Chem., 23: 882884.

22. Friedewald W. T., Levy R. I., and Fredrickson D. S. (1972): Estimation of the concentration of low-Density lipoprotein cholesterol in plasma without use of the preparative ultra centrifuge. Clin. Chem., 18: 499-502.

23. Levy, R. I. (1981): Cholesterol lipoprotein, apolipoproteins, and heart disease: Present status and future properties. Clin. Chem., 27: 653-662. 
24. Fruchart G. C. (1982): LDLCholesterol determination after separation of low density lipoprotein. Rev. Fr. Des. Lab., 7: 103-117.

25. Avram G. (1964): Quantitative Data. In: Biostatistics: An Introductory text. Chapter 2, page $53 \&$ 63. The MacMillan Company, New York, Collier MacMillan limited, London.

26. Steel R. G., and Torrie J. H. (1960): Principles and procedures of statistics. McGraw Hill, Book company, Inc., New York.

27. Cline G. W., Oetersen K. F., Krssak M., Shen J., Hundal R. S., Trajanoski Z., Inzucchi S., Dresner A., Rothman D. L., and Shulman G. I. (1999): Impaired glucose transport as a cause of decreased insulin-stimulated muscle glycogen synthesis in type 2 diabetes. N. Engl. J. Med., 341:240-245.

28. Pizzorno Jr J. F., Michael TM., and Herb T-B. (2002). In: The clinician's handbook of natural medicine.Pages 146-163. Harourt publishers limited, Edenburgh, London, N. Y.

29. Martin K (2003): Nutrient metabolism. Pages 742-745. Academic press, Elsevier.

30. Begum N., Sussman K. E., and Draznin B. (1991): Differential effects of diabetes on adipocyte and liver phosphotyrosine and phosphoserine phosphatase activities. Diabetes 40:16201629.

31. Nadiv O., Shinitzke M., Manu H., Hecht D., Roberts C. T.,
LeRoith D., and Zick Y., (1994): Elevated protein tyrosine phosphatase activity and increased membrane viscosity are associated with impaired activation of the insulin receptor kinase in old rats. Biochem. J., 298:443-450.

32. Eldar-Finkelman H., and Krebs E. G. (1997): Phosphorylation of insulin receptor substrate-1 by glycogen synthase kinase 3 impairs insulin action. Proc. Natl. Acad. Sci., 94:9660- 9664.

33. Imparl-Radosevich J., Deas S., Polansky M. M., Baedke D. A., Ingebrutsen T. S., Anderson R. A., and Graves D. J. (1998): Regulation of phosphorylase phosphatase (PTP-1) and insulin receptor kinase by fractions from cinnamon: implications for cinnamon regulation of insulin signaling. Horm. Res., 50:177182.

34. Jarvill-Taylor K. J., Anderson R. A., and Graves D. J. (2001): A hydroxychalcone derived from cinnamon functions as a mimetic for insulin in 3T3-L1 adipocytes. J. Am. Coll. Nutr., 20: 327-336

35. Dhuley J. N. (1999): Antioxidant effects of cinnamon (Cinnamomum verum) bark and greater cardamom (Amomum sabulatum) seeds in rats fed high fat diet. Indian J. Exp. Biol., 37:238-242.

36. RDA tables 2002: Dietary reference intake. WWW.nap.edu

37. Vincent J. B. (2000): The biochemistry of chromium. J. Nutri., 130: 715-718. 


$$
\begin{aligned}
& \text { تأثير القرفة على مستوى السكر والدهون فى مرضى النوع الثانى من البوال } \\
& \text { السكرى المصرينين } \\
& \text { د/ غادة زغلول عباس المعندين } \\
& \text { قسم الكيمياء الحيوية ـ المعهد القومى للتغذية ـ مصر }
\end{aligned}
$$



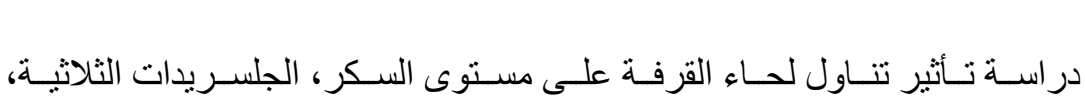

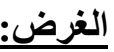

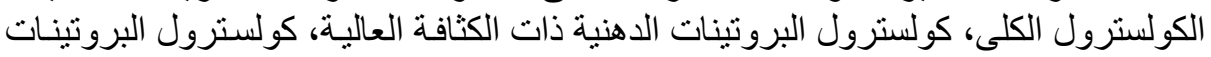

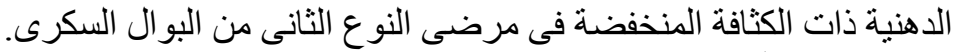

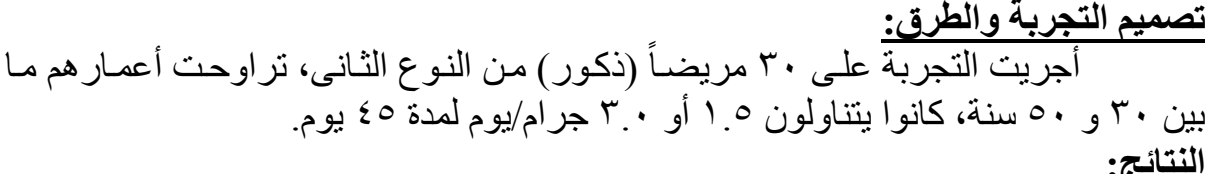

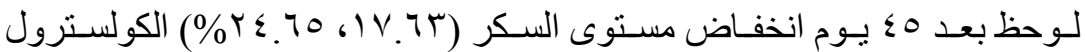

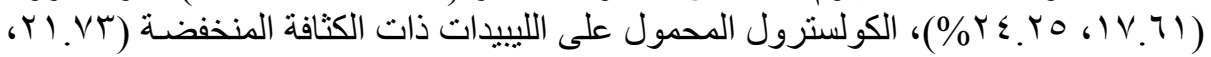

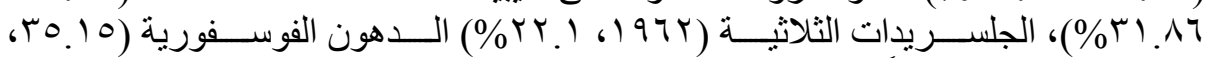

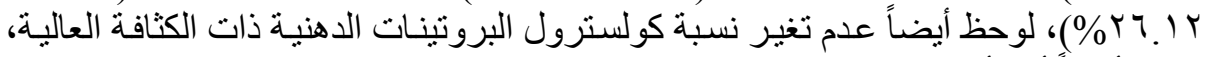

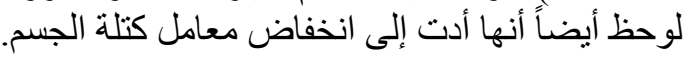

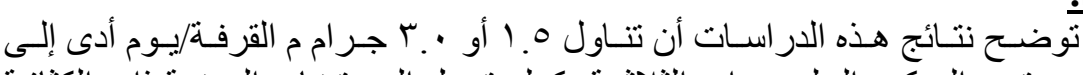

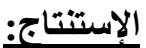

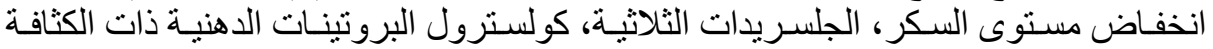

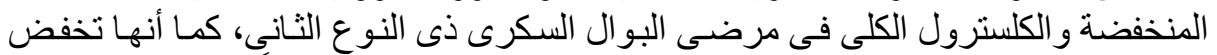

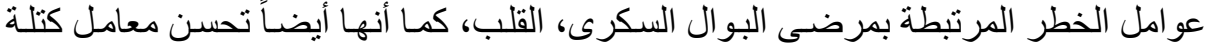
الجسم. 